\title{
New taxa and new combinations in Olearia (Asteraceae: Astereae) from south-eastern Australia
}

\author{
N.S. Lander
}

\begin{abstract}
Lander, N.S. (Western Australian Herbarium, Department of Conservation and Land Management, P.O. Box 104, Como, WA, Australia 6052) 1991. New taxa and new combinations in Olearia (Asteraceae: Astereae) from south-eastern Australia. Telopea 4(2): 145-164. Four new species of Olearia Moench (Asteraceae: Astereae) endemic to New South Wales are described: O. burgessii Lander, O. covenyi Lander, O. lasiophylla Lander, O. montana Lander. Eurybia oppositifolia F. Muell. is reinstated as Olearia oppositifolia (F. Muell.) Lander, also endemic to New South Wales. Two taxa previously described as varieties are raised to species rank as O. aglossa (Maiden \& Betche) Lander (formerly O. alpicola var. aglossa Maiden \& Betche), found in New South Wales and Victoria, and O. minor (Benth.) Lander (formerly O. pimeleoides var. minor Benth.), widespread in New South Wales, Victoria, South Australia and Western Australia. Descriptions, distribution maps and illustrations are provided, together with notes on affinities, habitat and conservation status.
\end{abstract}

\section{Introduction}

Prior to the publication of my account of Olearia Moench (Asteraceae: Astereae) in the forthcoming 'Flora of New South Wales' it is necessary to formally describe four new species. It is also necessary to make new combinations for three others: Eurybia oppositifolia F. Muell., synonymized under Olearia chrysophylla (DC.) Benth. by Bentham. (1867) and all subsequent authors, is recognized here as a distinct species; O. alpicola var. aglossa Maiden \& Betche and O.pimeleoides var. minor Benth. are raised to species rank as O. aglossa (Maiden \& Betche) Lander and O. minor (Benth.) Lander respectively.

My revisionary studies of the genus Olearia are ongoing and it is highly likely that infrageneric concepts will change. In the meantime, species are referred to the currently accepted sections.

The descriptive terminology used in this paper follows Radford (1986). In particular, I have used 'texture' to refer to the 'substance' or 'consistency' of an organ rather than to its surface configuration.

In the course of this study specimens from the following herbaria have been examined and annotated: AD, AUCK, BH, BM, BRI, CGE, CHR, CANB, CO, DBN, DNA, ED, FI, G, HO, K, KPBG, L, LD, MEL, NSW, P, PERTH, TCD, WELT, and the private herbarium of Cyril Keith Ingram of Mt Tomah, New South Wales (to be incorporated in NSW). 
Olearia aglossa (Maiden $\mathcal{E}$ Betche) Lander, stat. et comb. nov.

BASIONYM: Olearia alpicola var. aglossa Maiden \& Betche (1899: 147); Maiden \& Betche (1916: 193).

TyPe Citation: 'Jindabyne (W. Bäuerlen, January, 1890); Sawpit Creek, Mt Kosciusko (J.H. Maiden, January, 1898, and 1899).'

Syntypes: NeW South WaLES: Southern Tablelands: Jindabyne, Snowy River, W. Bäuerlen s.n., 17 Jan 1890 (NSW 179207); Mt Kosciusko, Sawpit Creek, J.H. Maiden s.n., Jan 1898 (MEL 36427, NSW 179208).

Possible sYNONYM: Eurybia alpicola var. rhodochaeta F. Muell. (1860b: 230). TYPE CITATION: 'In tractu Cobboras Mountains.' TYPE: not located (? MEL) - see Typification.

Shrubs to $1 \mathrm{~m}$ high. Vestiture of stems, abaxial surface of leaves and involucral bracts of intricate, multicellular, divaricately forked (T-shaped), eglandular hairs. Stems ascending, densely pale-brown-tomentose, becoming grey. Leaves opposite, spreading, petiolate; petiole stout, to $12 \mathrm{~mm}$ long; lamina flat, ovate, $24-90 \times 8-27 \mathrm{~mm}$, discolorous, green and glabrous adaxially, densely pale-brown-tomentose abaxially; texture coriaceous; venation obscure, reticulate; base acute or rounded; margin entire, weakly revolute; apex acute, mucronulate. Heads in terminal, corymbose conflorescences, pedunculate, disciform or radiate, 4-20 mm diam.; disc 2-5 mm diam. Peduncles to $25 \mathrm{~mm}$, with several small bracts merging into those of the involucre. Involucre narrowly conic; bracts 4-6-seriate, $2-5.3 \times 1.1-1.5 \mathrm{~mm}$. Outer involucral bracts ovate, flat; stereome greyish green and uniformly loosely tomentose abaxially; margin narrow, membranous, fimbriate; apex obtuse. Inner involucral bracts narrowly obovate, flat; stereome pale green and uniformly loosely tomentose abaxially; margin broad, membranous, fimbriate; apex broadly acute, with dense, multicellular, biseriate, capitate, glandular hairs. Receptacle convex. Marginal florets 2-4, female, uniseriate; corolla mostly filiform (rarely radiate), 4.4-10 mm long; tube glabrous; ligule (if present) ovate, c. 6.5 $x 1.5 \mathrm{~mm}$, white, glabrous, acute and minutely 3-lobed apically; stylar arms narrowly ligulate, $1.3-1.5 \mathrm{~mm}$ long. Disc florets $2-4$, bisexual; corolla narrowly infundibular, 5.5$6 \mathrm{~mm}$ long, yellow, glabrous; lobes 5, narrowly triangular, c. $2 \mathrm{~mm}$ long; anthers 2.4$2.6 \mathrm{~mm}$ long, sagittate and shorter than the filament collar basally, with narrowly ovate, terminal appendages; filament collar $0.7-0.8 \mathrm{~mm}$ long; stylar arms half-cylindric or half-clavate, $1.2-3 \mathrm{~mm}$ long, with triangular, sterile apical appendages bearing minute, botuliform papillae above the stigmatic lines. Achene narrowly obovoid, $0.3-$ $0.5 \times 1.3-2 \mathrm{~mm}$, light brown, glabrous or with apical tuft of duplex hairs, with 6-8 more or less prominent ribs; base acute with conspicuous central carpopodium. Pappus biseriate; bristles 53-75, minutely barbellate, pink, more or less equal in length to the disc corolla. Figure 1.

Distribution: Southern Tablelands of New South Wales and in the Victorian Alps (Figure 2).

HABITAT: Dry sclerophyll forest in mountainous areas.

FLOWERING PERIOD: December to February.

TYPIFICATION: Of the syntypes of Olearia alpicola var. aglossa cited in the protologue (Mueller 1860b), Maiden's Sawpit Creek specimen collected in 1899 has not been located.

At the end of the protologue of Eurybia alpicola F. Muell. [= Olearia alpicola (F. Muell.) F. Muell. ex Benth.], Mueller (1860b) describes an infraspecific taxon as ' $\beta$ rhodochaeta'. Although no type or other original material of E. alpicola var. rhodochaeta has been located, Mueller's diagnosis of it is consistent with material examined of 


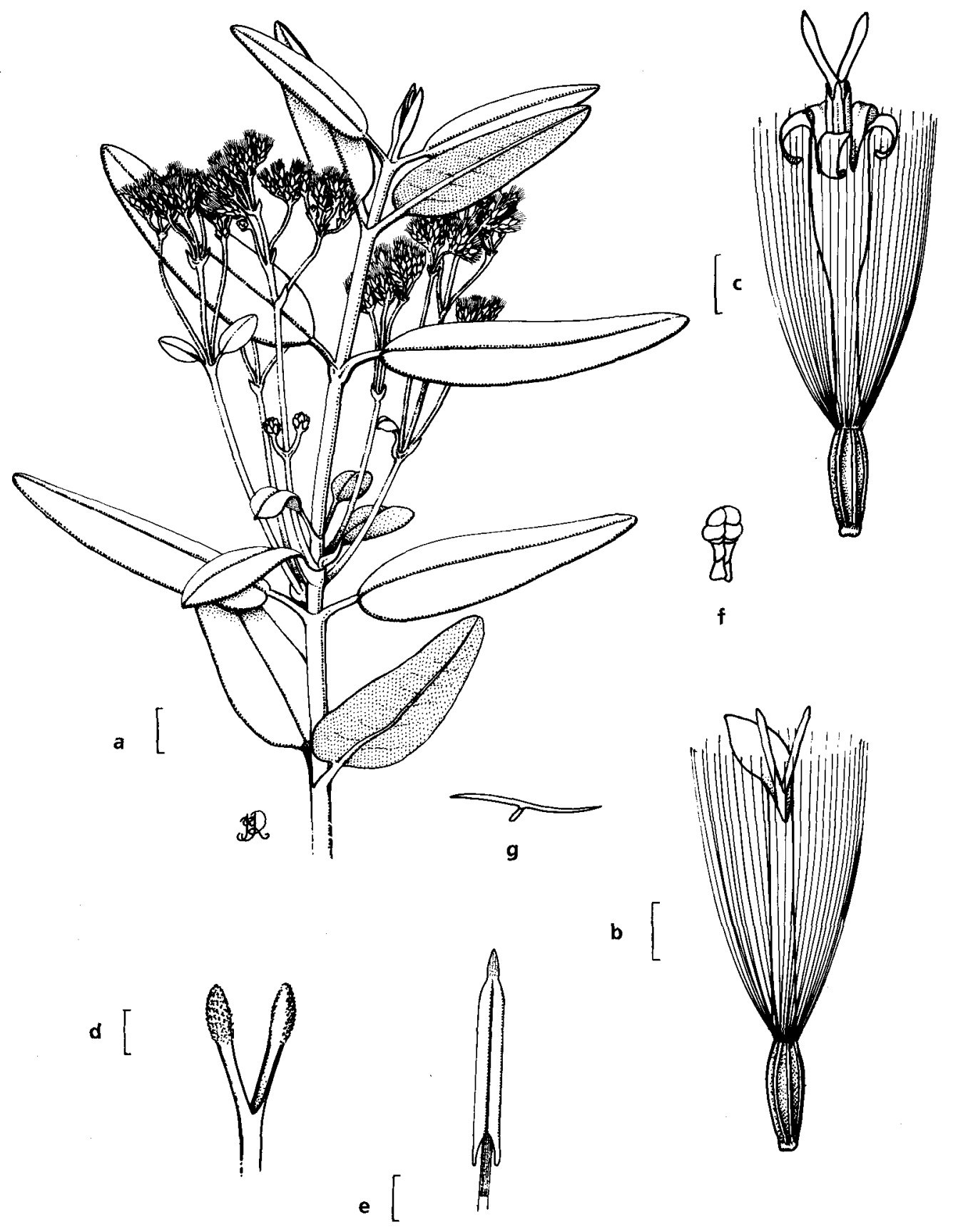

Figure 1. Olearia aglossa. a, habit. b, marginal floret. c, disc floret. d, stylar arms (from disc floret). e, anther. $\mathbf{f}$, multicellular, biseriate, capitate, glandular hair (from inner involucral bract). $\mathrm{g}$, multicellular, divaricately forked (T-shaped), eglandular hair (from leaf). From J.H. Maiden s.n. (syn NSW 179208). Scale bars: $a, b, c=1 \mathrm{rmm}$; , e, $f=0.5 \mathrm{~mm}$ 
O. aglossa, noting the pink pappus bristles ('pappi setis roseis'). Maiden \& Betche (1899) observe that 'specimens of O. alpicola from the Cobberas Mountains in Victoria, collected by F. v. Mueller, ... agree precisely with the rayless Mt Kosciusko form [i.e. their O. alpicola var. aglossa], except in the presence of the ray-flowers'; these specimens are possibly to be found amongst the Olearia material held in the supplementary collections at MEL. Although Maiden \& Betche thus cite what would seem likely to be types of Mueller's Eurybia alpicola var. rhodochaeta, they do not actually mention the latter name. It is very likely that this is a synonym of $O$. aglossa.

AfFINITIEs: The presence of divaricately forked trichomes on the vegetative surfaces of Olearia aglossa are typical of Olearia sect. Dicerotriche Archer ex Benth., where this species is best retained. Its affinities would seem to lie with $O$. alpicola from which it is readily distinguished: the leaves of $O$. alpicola are linear or elliptic; its heads are 19 $24 \mathrm{~mm}$ diam. with 6-7 marginal florets which are conspicuously ligulate, and 9-11 disc florets; and its pappus is of 61-85 white or straw-coloured bristles. The more widespread O.alpicola is found on the South Coast, Northern Tablelands, Southern Tablelands and North Western Slopes of New South Wales, and in the Victorian Alps.

Notes: Olearia aglossa appears to be unique amongst the Dicerotriche in the variable morphology of its marginal florets. Similar variation and reduction in the size of marginal florets (and even their complete absence) occurs independently in various species groups of Olearia which are otherwise typical of the genus - amongst the $O$. axillaris/O. tubuliflora group (section Eriotriche Archer ex Benth.) in Western Australia and South Australia, for instance.

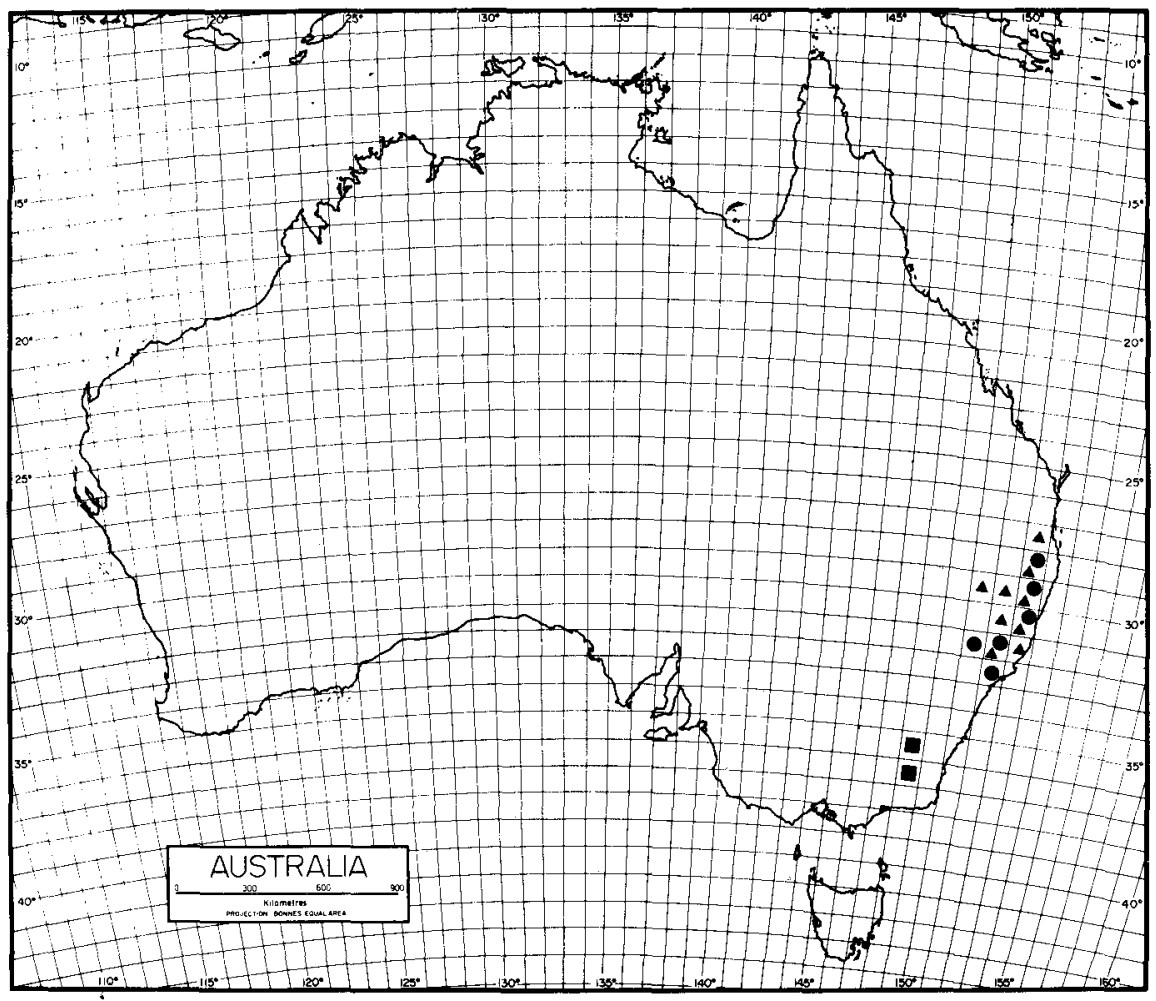

Figure 2. Distribution of Olearia aglossa ( $\boldsymbol{\square})$, O. covenyi $(\bullet)$ and O. oppositifolia $(\boldsymbol{\Lambda})$ indicating occurrence in $1^{\circ}$ squares. 
CONSERVATION STATUS: This species has a maximum geographic range of about $80 \mathrm{~km}$ and was last collected in 1954. It appears to warrant the category $2 \mathrm{~K}$ of Briggs \& Leigh (1988).

ETYMOLOGY: The specific epithet refers to the fact that the marginal florets of this taxon are usually filiform, lacking a distinct ligule.

Other sPeCimens eXAmined: New SOUth Wales: Southern Tablelands: Tumut Pond Reservoir [as 'Tumut Ponds'], G.W. Althofer s.n., Feb 1954 (NSW); Mt Kosciusko, J. McLuckie 101, Feb 1928 (CANB); s. loc., s. coll.,- [ex herb. W. Woolls] (NSW 127482).

\section{Olearia burgessii Lander, sp. nov.}

Species nova Olearia ramulosae probabiliter affinis a qua deficientia pilorum hispidorum, conicorum, multicellularium, uniseriatorum simplicium, eglandulosorum, praeclare distinguitur.

TYPE: New SOUTH WALEs: Central Coast: Thirlmere, C.E.B.H. Burgess s.n., 6 October 1959 (holo NSW, iso PERTH).

Shrub to $1.8 \mathrm{~m}$ high. Vestiture of stems, leaves and involucral bracts of intricate, multicellular, simple, flagellate, eglandular hairs and multicellular, biseriate, capitate, glandular hairs. Stems ascending, grey-tomentose, becoming reddish brown and subglabrous. Leaves alternate, scattered, spreading, sessile or subsessile; petiole to $2 \mathrm{~mm}$ long; lamina flat, obovate or elliptic, 3-13 $\times 1-4 \mathrm{~mm}$, discolorous, green and glabrous or with eglandular and glandular hairs scattered adaxially, grey-tomentose abaxially; texture chartaceous; venation indistinct apart from midvein; base narrowly cuneate; margin entire, weakly revolute; apex acute or rounded, muticous. Heads pedunculate, solitary, axillary or terminal on lateral (sometimes much reduced) branchlets, forming loose, leafy, paniculate conflorescences, radiate, 10-16 mm diam.; disc 5-8 $\mathrm{mm}$ diam. Peduncles to $12 \mathrm{~mm}$ long, with several small bracts grading into those of the involucre. Involucre campanulate; bracts 3-4-seriate, $2.2-4 \times 0.8-1 \mathrm{~mm}$. Outer involucral bracts somewhat carinate; stereome green, with eglandular hairs scattered uniformly and abaxially; margin narrow, membranous, fimbriate; apex acute with dense patch of eglandular and glandular hairs abaxially. Inner involucral bracts narrowly obovate, flat; stereome pale green, with eglandular hairs scattered abaxially and apically;margin narrow, membranous, fimbriate; apex acute with dense patch of eglandular and glandular hairs abaxially. Receptacle slightly convex. Marginal florets 8-11, female, uniseriate; corolla radiate, 7-7.5 mm long; tube with multicellular, biseriate, simple, eglandular hairs scattered apically; ligule narrowly ovate, 4-5.8 $\times 0.8-$ $1.5 \mathrm{~mm}$, white, glabrous, obtuse and minutely emarginate apically; stylar arms filiform, 1-1.5 mm long. Disc florets 6-10, bisexual; corolla infundibular, $3.7-4.6 \mathrm{~mm}$ long, yellow; tube with scattered, multicellular, biseriate, simple, eglandular hairs; lobes narrowly triangular, $1.3-1.5 \times 0.4-0.6 \mathrm{~mm}$; anthers $1.5-1.7 \mathrm{~mm}$ long, basally obtuse, with narrowly triangular sterile, terminal appendages; filament collar exceeding the anthers, 0.3-0.4 mm long; stylar arms half-ellipsoid, 1.1-1.3 mm long, with triangular, sterile apical appendages bearing minute, botuliform papillae above the stigmatic lines. Achene narrowly obovoid, $1.5-2 \times 0.5-0.6 \mathrm{~mm}$, light brown, \pm 8 -ribbed, more or less sericeous with duplex hairs. Pappus 2-seriate; bristles 26-40, more or less equal to the disc corolla, with or without an outer row of short bristles. Figure 3.

Distribution: Central Coast, Central Tablelands and Southern Tablelands of New South Wales (Figure 4).

HABITAT: In sandy loam over sandstone or shale, amongst dry sclerophyll forest.

FLOWERING PERIOD: July to November. 


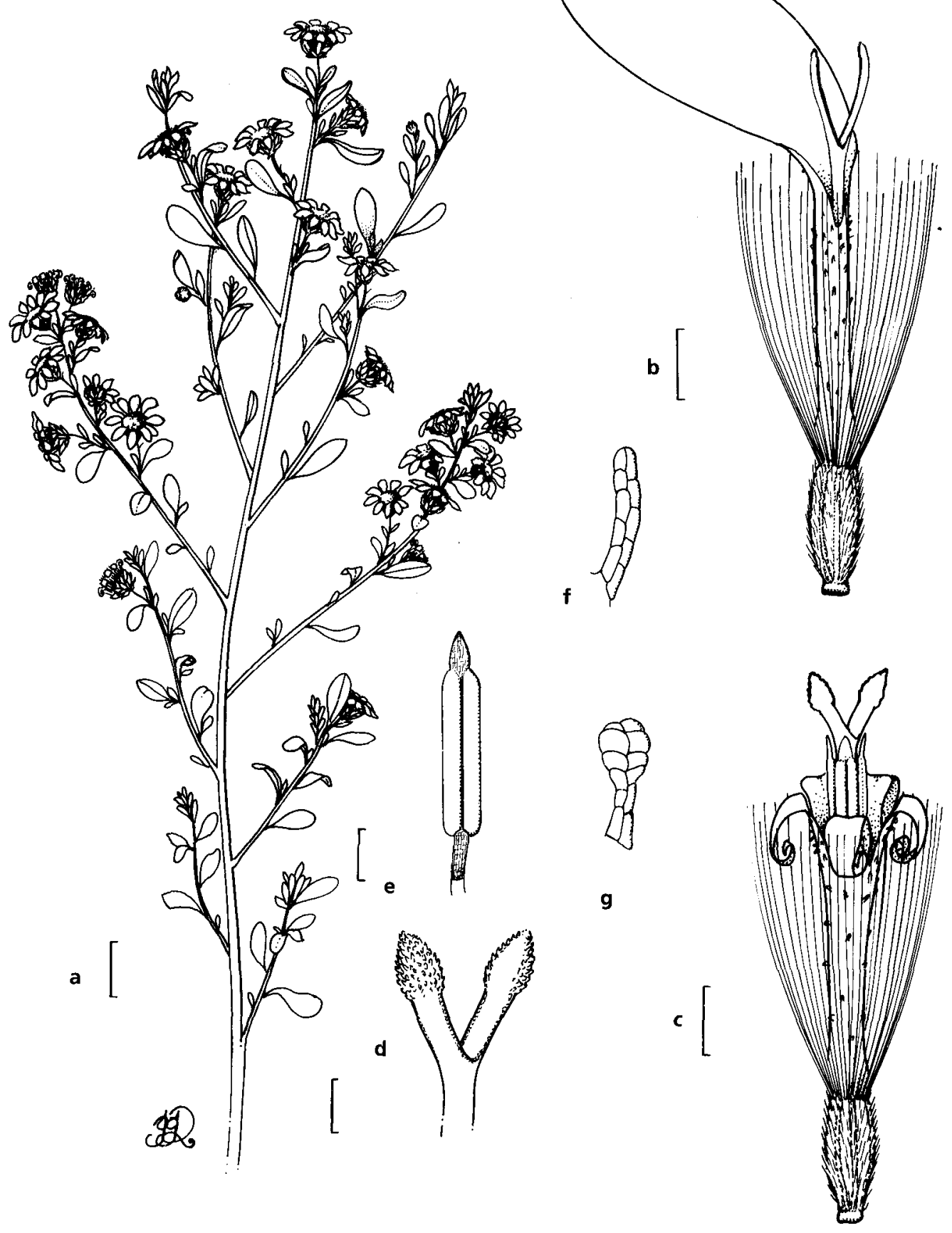

Figure 3. Olearia burgessii. a, habit. b, marginal floret. $\mathbf{c}$, disc floret. d, stylar arms (from disc floret). e, anther. f, multicellular, biseriate, simple, eglandular hair (from disc floret). $\mathbf{g}$, multicellular, biseriate, capitate, glandular hair (from leaf). From C. Burgess s.n. (holo NSW 182674). Scale bars: $\mathrm{a}=1 \mathrm{~cm} ; \mathrm{b}, \mathrm{c}=1 \mathrm{~mm} ; \mathrm{d}, \mathrm{e}=0.5 \mathrm{~mm}$. 
AFFINITIES: The preponderance of intricate, simple trichomes on the vegetative surfaces of Olearia burgessii is typical of Olearia sect. Eriotriche Archer ex Benth. where this species would seem best retained. Its affinities within sect. Eriotriche are as yet obscure but may lie with the rather variable and widespread $O$. ramulosa (Labill.) Benth., from which it is readily distinguished by the complete absence of hispid, conic, multicellular, uniseriate, simple, eglandular hairs.

Noтеs: Specimens of this species have been variously placed in herbaria under Olearia ramulosa (Labill.) Benth. and O.phlogopappa (Labill.) DC.

CONSERVATION STATUs: This species is known from two populations some $400 \mathrm{~km}$ apart and was last collected in 1971. It appears to warrant the category 3K of Briggs \& Leigh (1988).

Etymology: The specific epithet honours the late Rev. Colin Ernest Bryce Hawthorn Burgess (1907-1988), a keen amateur botanist, some of whose collections are held at NSW.

OtHeR SPECIMENS EXAMINED: New SOUTH Wales: Central Coast: Burragorang Lookout, D.F. Blaxell s.n., Nov 1961 (NSW); Hill Top, 1929, E. Cheel s.n., 1929 (NSW, PERTH); Hill Top, E. Cheel s.n., Nov 1930 (NSW); Bargo River, near Tahmoor, H. Salasoo 4786, Oct 1971 (NSW). Central Tablelands: Silverdale Road, E.F. Constable 3971, July 1947 (NSW). Southern Tablelands: Germanton \& Tumbarumba, W. Forsyth s.n., Nov 1900 (NSW, PERTH).

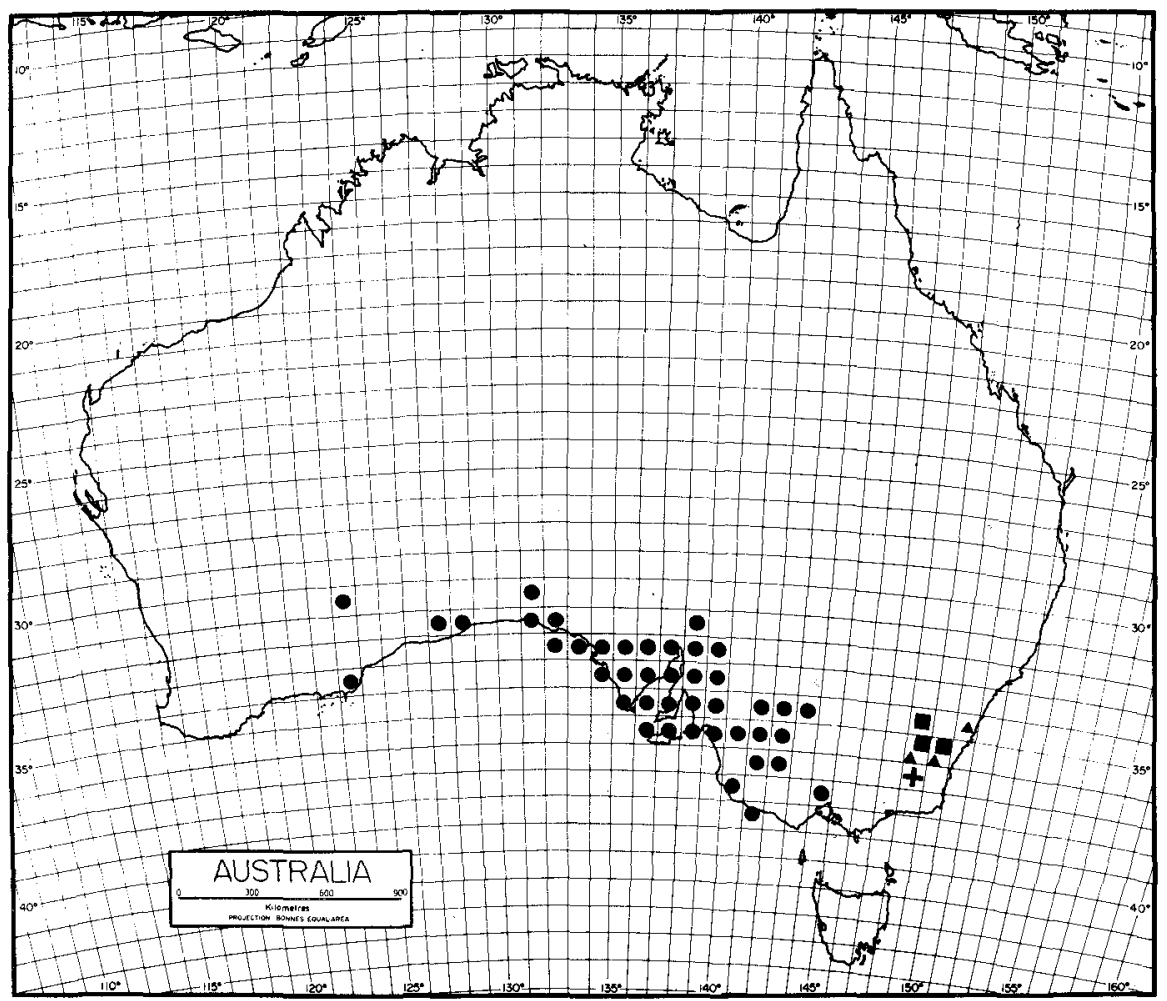

Figure 4. Distribution of Olearia burgessii $(\Lambda), O$ lasiophylla $(+), O$. minor $(\bullet)$ and $O$. montana (ש) indicating occurrence in $1^{\circ}$ squares. 
Olearia covenyi Lander, sp. nov.

Species nova Oleariae megalophyllae affinis a qua capitulis diametro minore (16.4-22 $\mathrm{mm}$ cf. 22.6-32 mm), flosculis paucioribus radiatis (2-4 cf. 5-9) et discis (3-4 cf. 9-14) praeclare distinguitur.

TyPE: New SOUTH Wales: Northern Tablelands: Gloucester Tops, R.G. Coveny s.n., 1 January 1967 (holo NSW 127260; iso PERTH).

[O. chrysophylla var. wilcoxii F. Muell. ex Maiden et Betche (1916: 193), nom. inval. see Notes.]

Shrub to $3 \mathrm{~m}$ high. Stems ascending, yellowish brown and densely tomentose, smooth. Vestiture of stems, leaves and outer involucral bracts of multicellular, uniseriate, divaricately forked (T-shaped), eglandular hairs. Leaves opposite, scattered, inclined, petiolate; petiole to $18 \mathrm{~mm}$ long, stout; lamina flat, ovate, $23-130 \times 12-50 \mathrm{~mm}$, discolorous, green and glabrous adaxially, yellowish brown and densely tomentose abaxially; texture coriaceous; venation distinct, reticulate; base rounded; margin entire, weakly revolute; apex rounded or obtuse, mucronulate. Heads in terminal, compound corymbose conflorescences, pedunculate, radiate, $16.4-22.2 \mathrm{~mm}$ diam.; disc 3-5 mm diam. Peduncles to $11 \mathrm{~mm}$ long, ebracteate. Involucre narrowly conic; bracts 3-4-seriate, $1.6-6.2 \times 0.9-1.3 \mathrm{~mm}$. Outer involucral bracts triangular, strongly carinate; stereome pale greenish brown, densely tomentose; margin membranous, fimbriate; apex broadly acute. Inner involucral bracts narrowly triangular or linear, somewhat carinate; stereome pale greenish brown, bearing divaricately forked, eglandular hairs centrally to apically and scattered, multicelluar, uniseriate, capitate, glandular hairs basally; margin membranous, fimbriate apically; apex narrowly acute. Receptacle convex. Marginal florets 2-4, female, uniseriate; corolla radiate, 10.9-12.5 mm long; tube glabrous; ligule elliptic or ovate, $6.7-8.6 \times 1.9-2.9 \mathrm{~mm}$, white, glabrous, acute and minutely 3-lobed; stylar arms narrowly clavate, $1.2-1.7 \mathrm{~mm}$ long. Disc florets $3-$ 4, bisexual; corolla infundibular, $6.0-8.3 \mathrm{~mm}$ long, yellow, glabrous; lobes 5 , narrowly triangular, 1.5-2.0 mm long; anthers $2.2-2.7 \mathrm{~mm}$ long, sagittate and shorter than the filament collar basally, with ovate terminal appendages; filament collar $0.5-0.6 \mathrm{~mm}$ long; stylar arms $1.5-1.7 \mathrm{~mm}$ long, with half-clavate apical apendages bearing botuliform papillae above the stigmatic lines. Achene narrowly obovoid, flattened, 2.0-2.9 x $0.5-0.7 \mathrm{~mm}$, brown, glabrous, with $6-8$ prominent ribs; base acute with conspicuous, central carpopodium. Pappus biseriate; bristles 41-82, minutely barbellate, more or less equal in length to the disc corolla. Figure 5.

Distribution: North Coast, Northern Tablelands, and North Western Slopes of New South Wales (Figure 2).

HABITAT: In wet sclerophyll forests in mountainous areas.

FLOWERING PERIOD: November to December.

AfFINITIES: The presence of divaricately forked trichomes on the vegetative parts of Olearia covenyi is typical of Olearia sect. Dicerotriche Archer ex Benth. where this species is best placed. Its affinities would seem to lie with O. megalophylla (F. Muell.) F. Muell. ex Benth. from which it is readily distinguished: the heads of O. megalophylla are 22.6-32 mm diam. with 5-9 ray florets and 9-14 disc florets. These two species are geographically disjunct and also differ in their flowering times: O. megalophylla is found on the Central Tablelands, Southern Tablelands and South Western Slopes of New South Wales, and in Victoria; it flowers from December to March.

NotEs: Specimens of this taxon held at MEL and NSW, including those of H. Beckler cited below, have been annotated by F. Mueller as 'Aster wilcoxii', a name never 

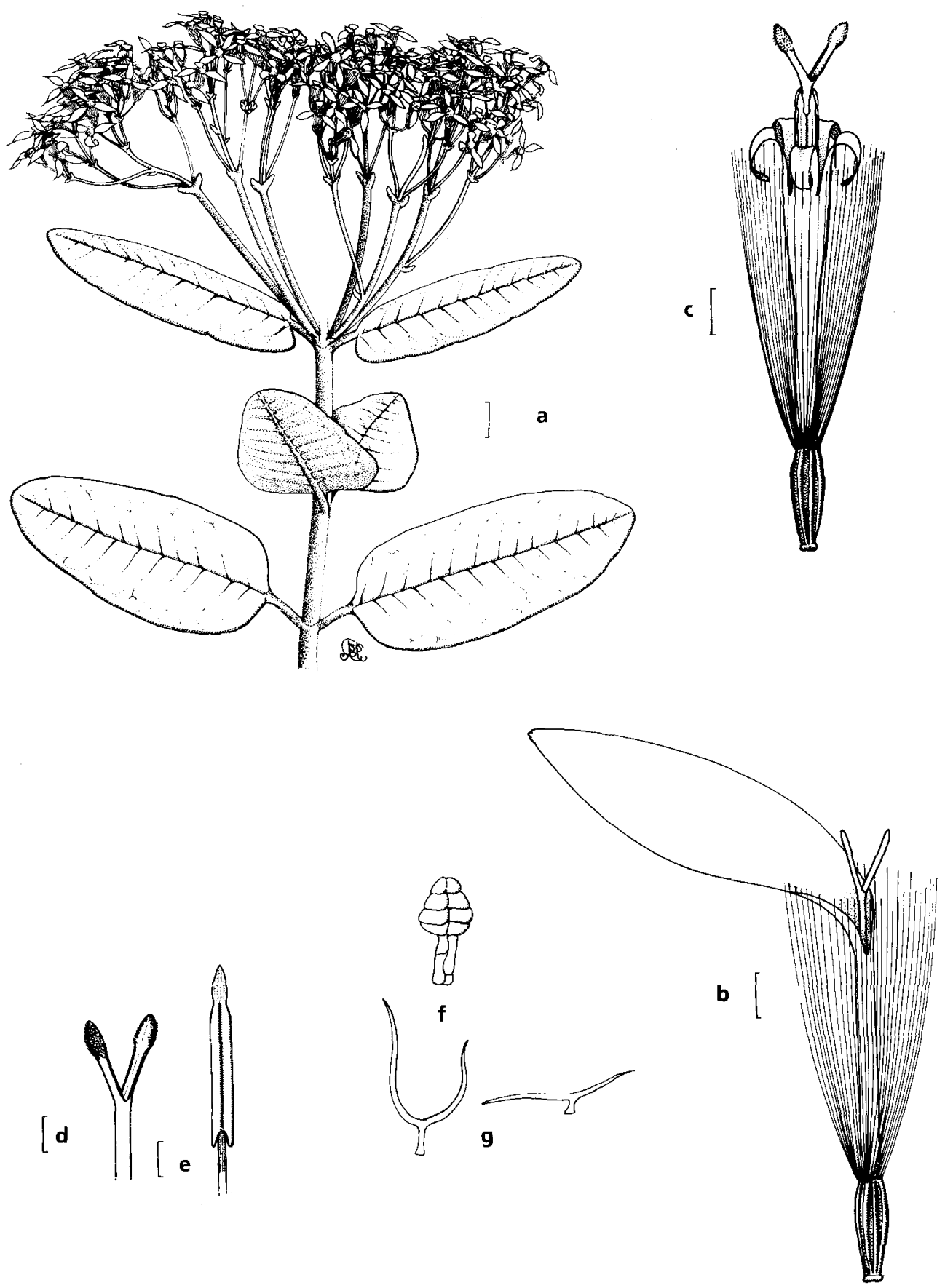

Figure 5. Olearia covenyi. a, habit. b, marginal floret. c, disc floret. $d$, stylar arms (from disc floret). e, anther. f, multicellular, biseriate, capitate, glandular hair (from inner involucral bract). $\mathbf{g}$, multicelluar, uniseriate, divaricately forked, eglandular hairs (from leaf). From R.G. Coveny s.n. (holo NSW 127260). Scale bars: $\mathrm{a}=1 \mathrm{~cm} ; \mathrm{b}, \mathrm{c}=1 \mathrm{~mm} ; \mathrm{d}, \mathrm{e}=0.5 \mathrm{~mm}$. 
actually published by Mueller or anyone else. Maiden \& Betche (1916) note 'O. chrysophylla var. wilcoxii F.v.M. M.S. in Melb. Herb.'; however, they provide neither a description or diagnosis of it nor a reference to a previously and effectively published description or diagnosis. In the event, the epithet is preoccupied at species rank in Olearia by O. wilcoxii Petrie, a New Zealand taxon.

CONSERVATION STATUS: This species is widely distributed, occurs in areas unlikely to experience a change in land use and is well collected. It is considered neither rare nor endangered.

ETYMoLogy: The specific epithet honours Robert George Coveny (1943- ), whose extensive collections have done so much to extend our knowledge of the flora of New South Wales.

Other SPecimens examined: New South Wales: North Coast: Macleay River, H. Beckler s.n., Nov 1875 (MEL, NSW 127265 p.p.); Bellingen, G. Hewitt s.n., Dec 1949 (NSW). Northern Tablelands: head of Bellingen River [as 'Bellinger'], Anonymous, 1864 (NSW); upper Clarence River, $H$. Beckler s.n., Nov 1875 (MEL, NSW 127265 p.p.); Yarrowitch, J.L. Boorman s.n., Dec 1912 (NSW); 'Guy Fawkes' \& Round Mt, J.L. Boorman s.n., Dec 1909 (NSW, PERTH); Murrurundi, R.H. Cambage s.n., Oct 1907 (NSW); Mt Bajimba, c. 18 miles [29 km] SSE of Tenterfield, E.F. Constable 7076, Alig 1966 (NSW, PERTH); Gloucester Tops, R.G. Coveny s.n., Jan 1967 (NSW); Kholwha Trail, Barrington Tops, C.K. Ingram \& P.D. Hind s.n., Feb 1983 (herb. C.K. Ingram); 'Perretts', Tyringham \& 'Bald Hill', Grafton-Armidale road, J.H. Maiden s.n., Dec 1893 (NSW 17961, 1272667, 127484); 'Guy Fawkes' \& Round Mt, J.H. Maiden s.n., Dec 1893 (NSW); Yarrowitch, J.H. Maiden s.n., Nov 1897 (NSW). North Western Slopes: Nundle, M.H. Simons 23, July 1913 (NSW).

\section{Olearia lasiophylla Lander, sp. nov.}

Species nova Oleariae stellulatae affinis sed pubescentia in superficiebus ambabus foliorum (folia $O$. stellulatae adaxialiter glabra vel subglabra, abaxialiter tomentulosa cinerea) et capitulis solitariis vel paucis diametro $22.4-27 \mathrm{~mm}$ (cf. conflorescentiae O. stellulatae foliosae paniculatae diametro 11-23.8 mm) praeclare distinguitur.

Type: New SOUTH WALES: Southern Tablelands: Grass Flat Creek, Pinnacle Road, W of Mt Townsend, N.C. Ford 76, 9 Jan 1959 (holo NSW 181859; iso CHR, MEL, PERTH).

Shrub to $1 \mathrm{~m}$ high. Vestiture of stems, leaves and involucral bracts of loose, intricate, multicellular, stellate, eglandular hairs. Stems ascending, densely stellate-hairy, yellowish becoming brown. Leaves alternate, scattered, subsessile; petiole to $4 \mathrm{~mm}$ long; lamina flat, elliptic, 7-55 x 4-16 mm, discolorous, dark green adaxially, pale green abaxially, densely stellate-hairy on both surfaces; texture flaccid; venation conspicuous, reticulate; margin entire or sinuate or coarsely dentate, flat; apex acute or obtuse, muticous. Heads terminal, on short branchlets, solitary or in small clusters, radiate, 22.4-27 mm diam., disc $0.8-1.3 \mathrm{~mm}$ diam.Peduncles to $34 \mathrm{~mm}$, with several leaf-like bracts grading into those of the involucre. Involucre hemispheric; bracts 3-4-seriate, 2.8-6 $\times 0.8-2 \mathrm{~mm}$. Outer involucral bracts triangular, carinate; stereome dark green and more or less uniformly and loosely stellate-hairy abaxially with multicellular, biseriate, glandular hairs scattered basally; margin undifferentiated, entire; apex acute. Inner involucral bracts narrowly elliptic, flat; stereome light green, subglabrous, with stellate hairs scattered apically; margin broad, membranous, entire; apex acuminate, fimbriate. Marginal florets 14-15, female, uniseriate; corolla radiate, 14-16 mm long; tube with multicellular, biseriate, simple, eglandular hairs scattered apically; ligule narrowly elliptic, $10-11 \times 2.4-3 \mathrm{~mm}$, white, glabrous, minutely 3-lobed apically; stylar arms filiform, 1.3-2 mm long. Disc florets 9-15, bisexual; corolla infundibular, $5.5-6.8 \mathrm{~mm}$ long, yellow, with multicellular, biseriate, simple, eglandular hairs scattered centrally to apically; lobes 5, triangular, 1.3-1.5 mm long; anthers $1.7-2 \mathrm{~mm}$ long, minutely sagittate and shorter than the filament collar basally, with narrowly triangular, sterile, 


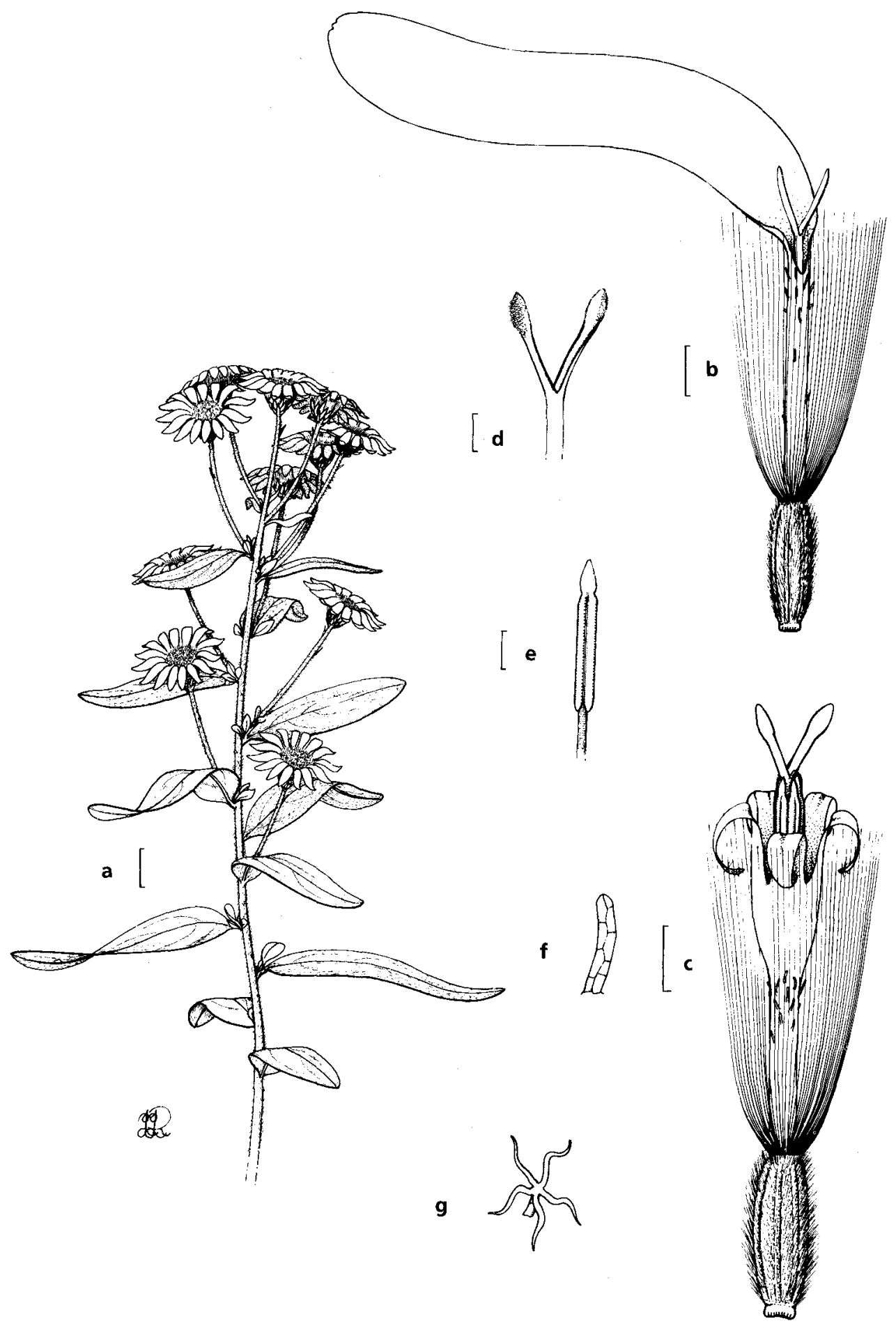

Figure 6. Olearia lasiophylla. a, habit. b, marginal floret. c, disc floret. $d$, stylar arms (from disc floret). e, anther. $\mathbf{f}$, multicellular, biseriate, simple, eglandular hair (from disc floret). $\mathbf{g}$, multicellular, stellate, eglandular hair (from leaf). a \& g from N.C. Ford 76 (holo NSW 181859). c-f, from M.E. Phillips 3517 (NSW). Scale bars: $\mathrm{a}=1 \mathrm{~cm} ; \mathrm{b}, \mathrm{c}=1 \mathrm{~mm}$;, $\mathrm{e}=0.5 \mathrm{~mm}$. 
terminal appendages; filament collar $0.5-0.6 \mathrm{~mm}$ long; stylar arms half clavate, 1-1.5 $\mathrm{mm}$ long, with half-clavate, sterile, apical appendages bearing botuliform papillae above the stigmatic lines. Achene flattened obovoid, $2.4-3.5 \times 0.8-1 \mathrm{~mm}$, light brown, sericeous with duplex hairs, 5-ribbed; base more or less acute, with conspicuous, central carpopodium. Pappus 2-seriate; bristles 39-52, more or less equal to the disc corolla in length, and an outer row of short bristles. Figure 6.

Distribution: Restricted to the vicinity of Geehi Reservoir on the Southern Tablelands of New South Wales (Figure 4).

HaBiтAT: Montane sclerophyll forests with Eucalyptus delegatensis R. Baker, on steep slopes.

FLOWERING PERIOD: November to February.

AFFINITIES: The presence of stellate hairs on the vegetative parts of Olearia lasiophylla is typical of Olearia sect. Asterotriche Archer ex Benth. (Bentham 1867), where this species would seem best placed. Its affinities appear to lie with $O$. stellulata (Labill.) DC., from which it is readily distinguished: the leaves of $O$. stellulata are glabrous or subglabrous adaxially and minutely grey-tomentose abaxially; its heads are in leafy, paniculate conflorescences and are 11-23.8 $\mathrm{mm}$ diam. The more widespread $O$. stellulata is found on the North, Central and South Coast and Tablelands of New South Wales, and in the Victorian and Tasmanian Alps.

Notes: Specimens of this species have been placed under O. stellulata in herbaria.

CONSERVATION STATUS: This species has a maximum geographic range of about $15 \mathrm{~km}$, is confined to the Kosciusko National Park and was last collected in 1972. It appears to warrant category $2 \mathrm{KC}$ of Briggs \& Leigh (1988).

ETYMology: The specific epithet refers to the loosely hairy leaves characteristic of this taxon, from Greek lasio-, woolly and -phylla, leaved.

Other SPECIMENS EXAMined: New SOUTH Wales: Southern Tablelands: $6.7 \mathrm{~km}$ SW of Geehi Reservoir Substation, P.N. Martensz 583, Feb 1972 (CANB); Pinnacle Track, above Geehi, M.E. Phillips 3517, Nov 1958 (NSW).

Olearia minor (Benth.) Lander, stat. et comb. nov.

BASIONYM: Olearia pimeleoides var. minor Benth. (1867: 479); Ewart (1931: 1114); Black (1965: 870); Jessop (1984: 67).

TYPE CITATION: 'Murray desert, F. Mueller; Rotton Island, Wilhelmi.'

LECTOTYPE (here designated): SOUTH Australia: Murray: Murray River, F. Mueller s.n., - (lecto K) - see Typification.

Lectoparatypes: South Australia: Eyre Peninsula: Boston Island, [J.F.C.J Wilhelmi s.n., - (MEL 1543742); Boston Island, [J.F.JC. Wilhelmi s.n., 1851 (MEL 1543738, p.p.). Murray: Murray Desert, F. Mueller s.n., - (MEL 1543743). - see Typification.

MisAPPLIED NAMES: Olearia floribunda auct. non (J. Hook.) Benth.: Wakefield (1956: 96); Willis (1973: 693), p.p.- see Notes.

Olearia brachyphylla auct. non (F. Muell. ex Sonder) Wakef.: Cooke in Jessop \& Toelken (1986: 1477, fig. 671a), p.p. - see Notes.

Shrub to $1.5 \mathrm{~m}$. Vestiture of stems, leaves and involucral bracts of multicellular, uniseriate, simple or sometimes dendritic, eglandular hairs and scattered multicellular, biseriate, capitate, glandular hairs. Stems ascending, greyish green becoming dark brown, pannose with eglandular and glandular hairs. Leaves alternate, scattered, 
sessile; lamina flat, obovate or elliptic, 1.5-8 x 1-2.5 mm, discolorous, adaxially green and subglabrous, abaxially grey-lanate; texture subcoriaceous; venation indistinct; base attenuate; margin entire, revolute; apex broadly acute or rounded, muticous. Heads terminal, solitary or in clusters of 2 or 3 , subsessile, conspicuously radiate, 11.6-22 mm diam.; disc 4-7 mm diam. Involucre conic; bracts 4-5-seriate, 1.9-5.3 x 0.7$1.5 \mathrm{~mm}$. Outer involucral bracts ovate, carinate; stereome pale green or yellow and densely lanate centrally to apically abaxially; margin chartaceous or membranous, slightly fimbriate; apex acute or rounded, ciliate. Inner involucral bracts linear or narrowly elliptic, somewhat carinate; stereome green, subglabrous to densely lanate apically; margin membranous, entire; apex acute or rounded, fimbriate. Receptacle weakly convex. Marginal florets 7-12, female, uniseriate; corolla radiate, 5.7-10.7 mm long; tube with eglandular hairs scattered apically; ligule elliptic or obovate, 3.8-7.5 x 1-2.5 mm, white, glabrous, minutely 3-lobed or sometimes emarginate apically; stylar arms filiform, 1.2-1.8 mm long. Disc florets 6-13, bisexual; corolla infundibular, 3.8-6 mm long, yellow, with eglandular and glandular hairs scattered apically; lobes 5, narrowly triangular, $0.9-1.8 \mathrm{~mm}$ long; anthers $1.3-1.9 \mathrm{~mm}$ long, obtuse to minutely sagittate, and shorter than filament collar basally, with triangular or obovate, sterile, terminal appendages; filament collar $0.3-0.5 \mathrm{~mm}$ long; stylar arms $1-1.7 \mathrm{~mm}$ long, with half-conic, sterile, apical appendages bearing botuliform papillae. Achene narrowly ellipsoid or obovoid, $0.8-1.7 \times 0.3-0.6 \mathrm{~mm}$, pale brown, subglabrous or densely glandular; carpopodium conspicuous, oblique. Pappus 1-2-3)-seriate; bristles 37-65, barbellate, more or less equal to the disc corolla in length, and (rarely) a third outer series of much shorter bristles.

Distribution: South Far Western Plains of New South Wales; Melbourne, North Central, Mallee, Wimmera and South West Study Areas of Victoria; Nullarbor, Flinders Ranges, Eastern, Eyre Peninsula, Northern Lofty, Murray, Yorke Peninsula, Southern Lofty, Kangaroo Island and South Eastern Regions of South Australia; the Eucla and Helms Districts of the Eremaean Botanical Province and the Roe District of the South-West Botanical Province of Western Australia (Figure 4).

НАвітAт: In red-brown loam or yellow-brown sand, on dunes or rocky slopes over sandstone or limestone, amongst mallee or open shrubland.

FLOWERING PERIOD: June to November.

Typification: Although the specimen at $\mathrm{K}$ chosen as the lectotype is labelled Murray River' it is clearly annotated by Bentham 'Olearia pimeleoides var. minor'. A small, supplementary label reads: 'FLORA AUSTRALIENSIS, Named by Mr. Bentham.'

The lectoparatype held at MEL bearing the locality 'Murray Desert' is annotated simply 'Eurybia'; the reverse of its label has been initialled by Bentham.

One of the lectoparatypes of Olearia pimeleoides var. minor, collected at Boston Island by J.F.C. Wilhelmi (MEL 1543742), bears a label annotated 'Eurybia pimeleoides var.'; the reverse of its label has been initialled by Bentham; an apparent duplicate of this (MEL 1543738 p.p.) bears a label annotated 'Eurybia s', also initialled on the reverse by Bentham; both specimens are clearly conspecific with the lectotype. However, a further lectoparatype held at $\mathrm{K}$ bearing the same collecting details and annotated by Bentham as 'Olearia pimeleoides var. minor' is clearly referable to O. exiguifolia (F. Muell.) F. Muell. ex Benth. I can find no reference to a locality named 'Rotton Island' either in gazetteers or on any of the labels of the 12000 or so specimens of Olearia examined in the course of my studies on this genus, thus I take it for a simple transcription error for Boston Island, situated off Port Lincoln in South Australia.

AfFINITIES: The presence of intricate dendritic hairs on the vegetative parts of Olearia minor is typical of Olearia sect. Eriotriche where this species would seem best retained. 
Its affinities appear to lie with $O$. pimeleoides (DC.) Benth. sens. strict. from which it is readily distinguished: the leaves of $O$. pimeleoides are $3-25 \times 1-6.5 \mathrm{~mm}$; its heads are pedunculate (with peduncles to $85 \mathrm{~mm}$ long) and are $20.5-30 \mathrm{~mm}$ in diameter, with 8-25 ray florets and 14-29 disc florets. O. pimeleoides sens. strict. is found extensively in New South Wales, southern Queensland, Victoria, South Australia and Western Australia.

Notes: Specimens of Olearia minor have been a source of much confusion in the literature where they have been placed under various species in Olearia sect. Eriotriche, notably $O$. brachyphylla, $O$. floribunda, and $O$. pimeleoides. In herbaria they have also been placed under O. exiguifolia and O. iodochroa (F. Muell.) F. Muell. ex Benth.

Cooke (in Jessop \& Toelken 1986: 1477-8) has interpreted Olearia brachyphylla very broadly, synonymizing under it both O. exilifolia (F. Muell.) Benth. and O. pimeleoides var. minor. I have circumscribed O.brachyphylla more narrowly, uniting it with $O$. exilifolia but maintaining $O$. pimeleoides var. minor as a distinct taxon worthy of specific rank. O. minor is not at all easily confused with O. brachyphylla. Notably, the leaves of $O$. brachyphylla are oblong, 2-3 x 0.5-1 mm and incurved; and its heads are 3-4 $\mathrm{mm}$ in diameter with 2-3 ray florets and 3-4 disc florets. O. brachyphylla is disjunct in its distribution, occurring in the Eyre Peninsula, Murray, South Eastern and Southern Lofty Regions of South Australia, and in the Eyre District of the South-West Botanical Province of Western Australia.

Wakefield (1956: 96) and Willis (1973: 693) included specimens of Olearia minor under O. floribunda. Willis suggested that these may be of hybrid origin: I can see nothing to support this contention. Olearia minor is readily distinguished from O. floribunda. The leaves of the latter are crowded and 0.3-1 $\mathrm{mm}$ wide with flat margins; its heads are 8-13 $\mathrm{mm}$ in diameter with 3-7 ray florets and 3-9 disc florets, and they are arranged in exceedingly dense, leafy, paniculate conflorescences; its pappus comprises 27-37 long bristles with an outer row of much shorter bristles. O. floribunda is widely distributed on the Central and South Western Slopes, Southern Tablelands and South Western Plains of New South Wales; the Eastern Highlands and West Gippsland Coastal Plain of Victoria; the Eastern, Eyre Peninsula, Murray, South Eastern, Southern Lofty and Yorke Peninsula Regions of South Australia; and in Tasmania.

Willis (1973: 692) notes under Olearia iodochroa 'mauve-headed populations' from the Brisbane Ranges of Victoria, referred here to $O$. minor, suggesting that these may have arisen as a result of hybridism between $O$. pimeleoides and $O$. ramulosa (Labill.) Benth. Like those of many Astereae, the white ligules of the ray florets of this suite of specimens sometimes dry mauve; however, there is nothing on their labels to suggest that they exhibit this colour in life. Again there is nothing to suggest that $O$. minor is of hybrid origin: O. minor is easily distinguished from $O$. iodochroa. The leaves of the latter are densely yellowish lanate abaxially; its involucral bracts have characteristically dark purple margins; its heads have 15-20 ray florets. O. iodochroa is confined to the Southern Tablelands of New South Wales and the Eastern Highlands of Victoria and does not overlap geographically with $O$. minor.

For the differences between O.minor and O. pimeleoides see the diagnosis and Affinities above.

CONSERvation Status: This species is very widely distributed across southern arid Australia, occurs in several National Parks, and is well collected. It is considered neither rare nor endangered. 
ETYMOLOGY: The specific epithet refers to the heads of this taxon, which are noticeably smaller than those of $O$. pimeleoides, from which it has been segregated.

OTHER SPECIMENS EXAMINED: New SOUTh WALES: South Far Western Plains: Balranald, T.P. Lucas 66, 1878 (MEL, PERTH); Paika [Lake]-Balranald, [T.P. Lucas] 66, Aug 1878 (MEL); 28 km W of Euston, W.E. Mulham s.n., Oct. 1978 (NSW). VICTORIA (selection from a total of 60): Melbourne: Brisbane Ranges, J. Anderson 320, Nov 1968 (AD, MEL). Mallee: Wentworth, Mrs Farr s.n., - (MEL); 5 miles [8 km] E of Peebinga, J.H. Willis s.n., Aug 1955 (MEL). South West: Mt Richmond National Park, R.J. McHugh s.n., Mar 1975 (MEL). South Australia (selection from a total of 226): Nullarbor: 4 miles [6 km] SW of Maralinga, L.D. Williams s.n., Aug 1977 (AD). Murray: Pinnaroo, J.B. Cleland s.n., Aug 1927 (AD). South Eastern: Biscuit Flat, Comaum, C.R. Alcock 175, Nov 1969 (AD). WESTERN Australia: South-West Botanical Province: Roe District: Mt Ragged, S.T. Brooks s.n., 1889 (MEL). Eremaean Botanical Province: Helms District: $2.4 \mathrm{~km} \mathrm{~W}$ of 'Nippon Junction', D.J. Pearson 442, June 1988 (PERTH). Eucla District: 'Eucla', J. Richards s.n., 1877 (MEL); 100 miles [161 km] E of Madura Pass, s. coll., - (NSW 180795).

\section{Olearia montana Lander, sp. nov.}

Species nova Oleariae stellulatae affinis sed flosculis numerosioribus radiatis (17-28 cf. 11-16) et discis (15-13 cf. 9-14) praeclare distinguitur.

TyPE: New SOUth Wales: Southern Tablelands: Tinderry Mountains, T.G. Hartley 13407, October 1971 (holo CANB; iso CHR, K, NSW, PERTH).

Shrub to $2 \mathrm{~m}$ high. Vestiture of stems, abaxial surfaces of leaves and involucral bracts tomentose with multicellular, stellate hairs. Stems ascending, smooth, yellowish brown becoming greyish brown, striate. Leaves alternate, scattered, divergent, petiolate; petiole stout, to $5 \mathrm{~mm}$ long; lamina flat, elliptic, $13-43 \times 7-18 \mathrm{~mm}$, discolorous, green and subglabrous adaxially, pale-brown-tomentose abaxially; texture subcoriaceous; venation distinct, reticulate; base obtuse or rounded; margin serrate, flat; apex obtuse, muticous. Heads in paniculate conflorescences, pedunculate, radiate, $18-27 \mathrm{~mm}$ diam.; disc 6-9 $\mathrm{mm}$ diam. Peduncle to $15 \mathrm{~mm}$ long, with several leaf-like bracts grading into those of the involucre. Involucre hemispheric; bracts 3-4-seriate, 4.2-6.6 x 0.9-2.0 mm. Outer involucral bracts triangular, flat; stereome yellowish brown, uniformly densely stellate-tomentose, with uniseriate, capitate glandular hairs scattered basally; margin chartaceous, purple, ciliate; apex acute. Inner involucral bracts narrowly linear or triangular, flat; stereome pale green, densely stellate-tomentose centrally to apically, with scattered glandular hairs centrally; margin membranous, entire, fimbriate apically; apex acute. Receptacle convex. Marginal florets 17-28, female, uniseriate; corolla radiate, 9.5-12.8 $\mathrm{mm}$ long; tube with stellate hairs and multicellular, biseriate, simple, eglandular hairs scattered centrally to apically; ligule narrowly elliptic, $6-9$ x 1.8-2.8 $\mathrm{mm}$, mauve, glabrous; apex minutely 2-lobed; stylar arms narrowly filiform, 1.3-1.8 $\mathrm{mm}$ long. Disc florets 15-31, bisexual; corolla infundibular, 5.3-7 $\mathrm{mm}$ long, purple, with multicellular, uniseriate, simple, eglandular hairs scattered centrally-apically; lobes 5, narrowly triangular, 1.1-1.6 mm long; anthers 2-2.3 $\mathrm{mm}$ long, sagittate and shorter than the filament collar basally, with triangular terminal appendages; filament collar 0.3-0.4 mm long; stylar arms 1-1.9 mm long, with half-conic apical appendages bearing botuliform papillae. Achene narrowly obovoid, flattened, 1.3-2.4 x 0.5-0.8 mm, dark brown, glabrous, 6-ribbed; base acute with conspicuous, oblique carpopodium. Pappus multiseriate; bristles 35-71, minutely barbellate, subequal to the disc corolla, with an outer series of 10-35 shorter bristles. Figure 7.

DistRiButTon: Occurs in the Tinderry Range, Brindabella Range and Scabby Range on the Southern Tablelands of New South Wales (Figure 4).

HABITAT: In dry shallow soils over granite, on rocky slopes amongst sclerophyll forest and Eucalyptus rossii woodland. 

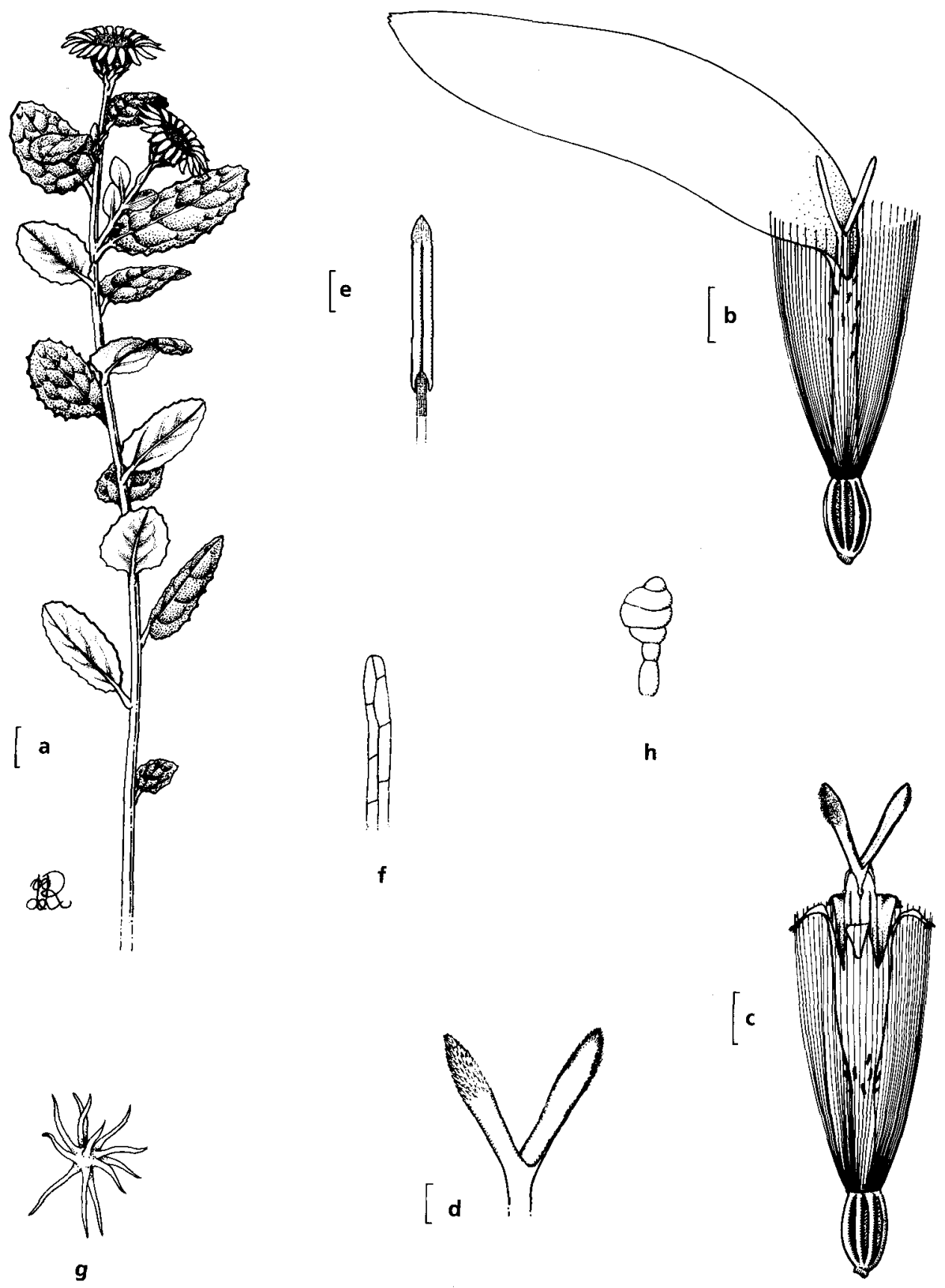

Figure 7. Olearia montana. a, habit. b, marginal floret. $\mathbf{c}$, disc floret. $\mathbf{d}$, stylar arms (from disc floret); e, anther. f, multicellular, uniseriate, capitate, glandular hair (from outer involucral bract). g, multicellular, biseriate, simple, eglandular hair (from disc floret). h. multicellular, stellate, eglandular hair (from leaf). From T.G. Hartley 13407 (holo CANB). Scale bars: a $=1 \mathrm{~cm}$; b, $c=1 \mathrm{~mm} ; \mathrm{d}, \mathrm{e}=0.5 \mathrm{~mm}$. 
FLOWERING PERIOD: September to October.

AfFINITIES: The presence of stellate hairs on the vegetative parts of Olearia montana is typical of Olearia sect. Asterotriche where this species would seem best placed. Its affinities appear to lie with $O$. stellulata, from which it is readily distinguished: the heads of $O$. stellulata have 11-16 ray florets and 9-14 disc florets. The widespread $O$. stellulata is found on the North, Central and South Coast and Tablelands of New South Wales, and in the Victorian and Tasmanian Alps.

Notes: This is the species referred to as 'Olearia sp. 2' by Briggs \& Leigh (1988).

CONSERVATION STATUS: This species has a maximum geographic range of about $135 \mathrm{~km}$ and field notes indicate that it is rare. It was last collected in 1975. Briggs \& Leigh (1988) note its occurrence in Namadgi National Park (Brindabella Range, $35^{\circ} 27^{\prime} \mathrm{S}$, $\left.148^{\circ} 46^{\prime} \mathrm{E}\right)$, Scabby Range Nature Reserve ( $34^{\circ} 45^{\prime} \mathrm{S}, 148^{\circ} 52^{\prime} \mathrm{E}$ ) and Tinderry Nature Reserve; they give it the category $2 \mathrm{RC}$. In view of the fact that its geographic range actually exceeds $100 \mathrm{~km}$ this should now be corrected to $3 \mathrm{RC}$.

ETYMOLOGY: The specific epithet refers to the montane habit of this species.

Other SPecimens eXAmined: New SOUTh Wales: Southern Tablelands: summit of Tinderry Mt, L. Costerman s.n., Jan 1975 (NSW 181855); 13.7 km ESE of Michelago, Tinderry Mts, R.G. Coveny 6347, Sep 1967 (NSW); 6 miles [9.6 km] E of Michelago on Jerangle Road, Tinderry Mts, M. Evans 2620, Sep 1967 (CANB, CHR, K, L, NSW); Tinderry Gap, T. $\mathcal{E}$ S. Whaite 3132, Oct 1966 (NSW); Tinderry Range, Walker ANU 1189, Oct 1963 (CANB).

Olearia oppositifolia (F. Muell.) Lander, comb. nov.

BAsIONYM: Eurybia oppositifolia F. Muell. (1860a: 88-89).

TYPE CitATION: 'Ad Ripas rupestres torrentium montis Guy Fox Peak, ad flumen Anne et in monte Mitchell, altitudine 3000-4000'. Dr. Beckler.'

Syntypes: New South Wales: Northern Tablelands: River Ann, [H. Beckler s.n.], - (MEL 36433); on the rocky banks of the rivers Sarah and Anne, [collector illegible], - (MEL 36434).

Misapplied names: Olearia chrysophylla auct. non (DC.) Benth.: Bentham (1867: 468), p.p.; C. Moore (1884: 33), p.p.; Maiden \& Betche (1916: 193), p.p. Aster chrysophyllus auct. non (DC.) A. Cunn. ex C. Moore: Moore (1893: 267), p.p.

Shrub to $2.3 \mathrm{~m}$. Vestiture of stems, abaxial surfaces of leaves and involucral bracts of multicellular, divaricately forked (T-shaped), eglandular hairs and multicellular, biseriate, capitate glandular hairs. Stems ascending; bark smooth, pale brown, grey when mature. Leaves opposite, scattered, inclined, petiolate; petiole to $12 \mathrm{~mm}$ long; lamina flat, ovate or elliptic, 14-110 × 6-39 mm, discolorous, green and glabrous or subglabrous adaxially, pale-brown-, rarely purple-sericeous abaxially; texture coriaceous; venation distinct, pinnate/reticulate; base narrowly to broadly acute, obtuse or rounded; margin denticulate, sometimes entire or sinuate when young, flat or weakly revolute; apex acute or rounded, mucronulate. Heads in terminal, compound-corymbose conflorescences, pedunculate, radiate, $18.6-22.8 \mathrm{~mm}$ diam.; disc 4-7 $\mathrm{mm}$ diam. Peduncles to $50 \mathrm{~mm}$ long, with or without several leaf-like bracts grading into those of the involucre. Involucre conic to narrowly conic; bracts 3-4-seriate, $2.5-6 \times 1-1.6 \mathrm{~mm}$. Outer involucral bracts ovate, cymbiform; stereome pale green, uniformly densely sericeous; margin membranous, with scattered multicellular, biseriate, capitate, glandular hairs, fimbriate; apex narrowly rounded. Inner involucral bracts narrowly ovate, somewhat cymbiform; stereome pale green, uniformly weakly sericeous; margin membranous, with scattered glandular hairs; apex rounded. Receptacle strongly con- 


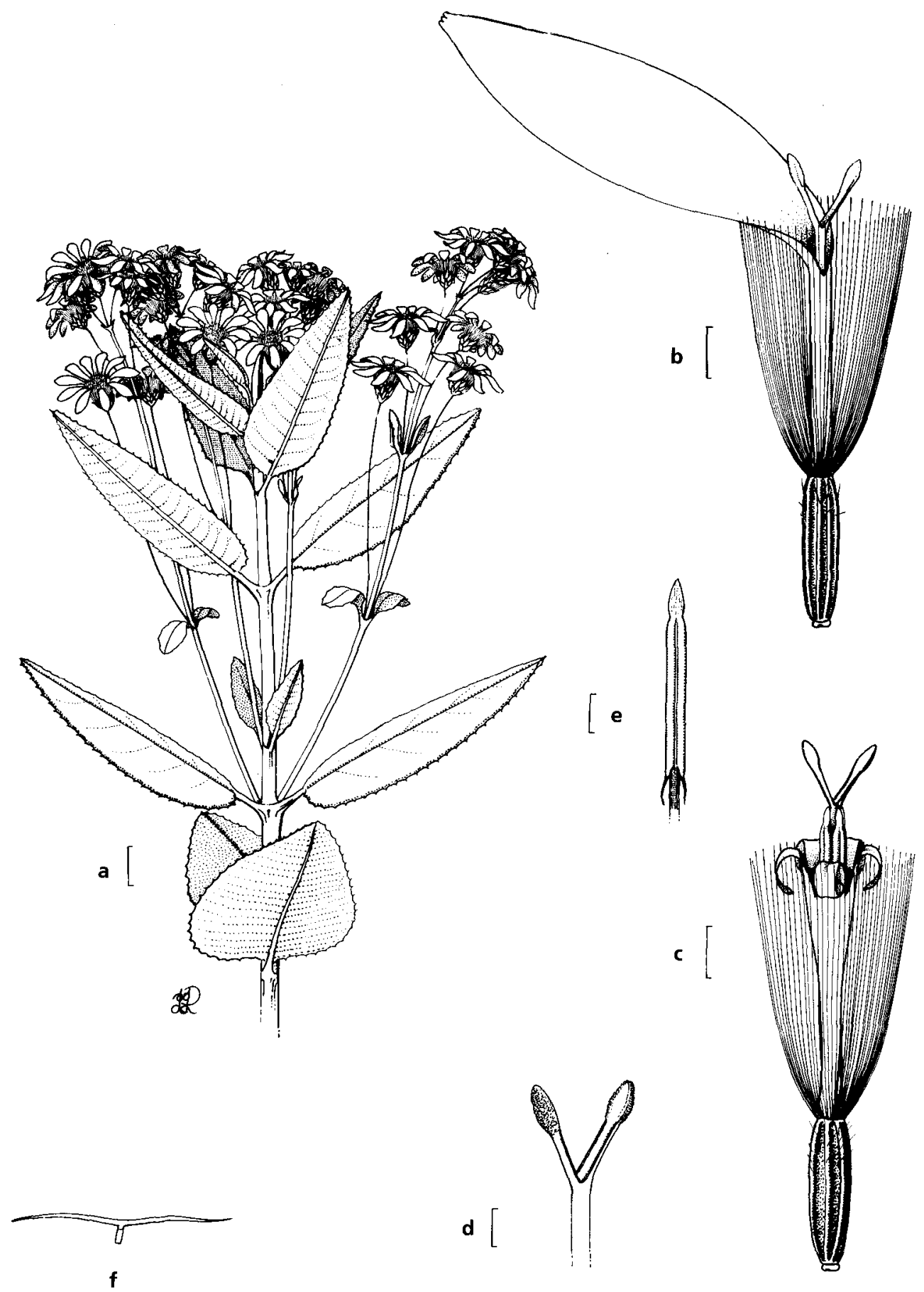

Figure 8. Olearia oppositifolia. a, habit; $\mathbf{b}$, marginal floret. $\mathbf{c}$, disc floret; $\mathbf{d}$, stylar arms (from disc floret); e, anther; $\mathbf{f}$, multicellular, divaricately forked (T-shaped), eglandular hair (from leaf). From J.L. Boorman s.n. (NSW 127485). Scale bars: $\mathrm{a}=1 \mathrm{~cm} ; \mathrm{b}, \mathrm{c}=1 \mathrm{~mm}$;, $\mathrm{e}=0.5 \mathrm{~mm}$. 
vex. Marginal florets 4-6, female, uniseriate; corolla radiate, $11.4-13 \mathrm{~mm}$ long; tube glabrous; ligule, narrowly elliptic, $8-9 \times 1.8-2 \mathrm{~mm}$, white, glabrous; apex minutely 3-lobed; stylar arms filiform, 1.1-1.4 mm long. Disc florets 6-11, bisexual; corolla infundibular, 6-7 mm long, yellow, glabrous; lobes 5, triangular, 1.5-1.9 mm long; anthers $2.2-2.5 \mathrm{~mm}$ long, narrowly acute (rarely caudate) and shorter than the filament collar basally, with narrowly elliptic or narrowly ovate terminal appendages; filament collar $0.4-0.7 \mathrm{~mm}$ long; stylar arms $1.2-1.9 \times 0.2-0.3 \mathrm{~mm}$, with half-ovoid apical appendages bearing botuliform papillae. Achene very narrowly obloid, $2.2-3 \mathrm{x}$ $0.5-0.7 \mathrm{~mm}$ long, pale brown to brown, glabrous or subglabrous with duplex hairs scattered apically, distinctly 5-8-ribbed; base acute with conspicuous, central carpopodium. Pappus biseriate; bristles 44-77, subequal to the disc corolla with several shorter bristles. Figure 8.

Distribution: Restricted to the North Coast and Northern Tablelands of New South Wales (Figure 2).

HABITAT: In wet and dry sclerophyll forests.

FLOWERING PERIOD: November to January.

Notes: This taxon was synonymised under Olearia chrysophylla by Bentham (1867: 468) and subsequent authors. It is the undescribed species referred to by Beadle (1980: 636).

AfFINITIES: The multicellular, divaricately branched (T-shaped) eglandular hairs on the vegetative surfaces of Olearia chrysophylla are typical of Olearia sect. Dicerotriche where this species would seem best retained. Its affinities appear to lie with $O$. chrysophylla, from which it is readily distinguished: the leaf margins of O. chrysophylla are entire, only sometimes sinuous or indistinctly and irregularly denticulate; its heads are $21.6-27.6 \mathrm{~mm}$ diam. with 12-14 disc florets; its pappus comprises 73-85 bristles. O. oppositifolia and chrysophylla are geographically disjunct: the latter is restricted to the Central Coast and Central Tablelands of New South Wales.

CONSERVATION STATUS: This species is widely distributed in areas unlikely to experience any change in land use, occurs in National Parks and is well collected. It is considered neither rare nor endangered.

ETYMology: The specific epithet refers to the opposite leaves of this taxon.

Other specimens examined (selection from a total of 59): New South Wales: North Coast: Drake, J.L. Boorman s.n., Oct 1901 (AD, NSW 127485). Northern Tablelands: Gloucester Tops, R.G. Coveny s.n., Jan 1966 (NSW, PERTH); 19.2 miles [31 km] E of Glen Innes on Grafton Road, M. Gray 3005b, Dec 1953 (CANB, NSW); $20 \mathrm{~km}$ E of Ebor, N.S. Lander 514. Oct 1974 (NSW); Gibraltar Range National Park, N.S. Lander 533, Oct 1974 (NSW); 1 mile [1.6 km] S of Point Lookout, J.B. Williams s.n., Dec 1966 (NE - n.v., NSW).

\section{Acknowledgements}

It is a pleasure to thank Mr J.J. Rainbird and Ms Karina Knight for their expert research assistance; I also thank Mr Rainbird for the illustrations in this paper. I am grateful to Mr M.I.H. Brooker for providing the Latin diagnoses. I thank Mr C.K. Ingram for making the invaluable suite of Olearia specimens from his personal herbarium available to me for study. 
Much vital background work towards my ongoing revision of Australian Olearia was carried out during my assignment as Australian Botanical Liaison Officer at the Royal Botanic Gardens, Kew, London, during 1984-5 and during visits to the National Herbarium of Victoria, Melbourne, in 1986 and 1987. This work has been further supported by Australian Biological Resources Study Grants in 1988 and 1989.

\section{References}

Bentham, G. (1867) Flora Australiensis, vol. 3. (Lovell Reeve \& Co.: London).

Beadle, N.C.W. (1980) Students flora of north-eastern New South Wales, vol. 4. (University of New England: Armidale).

Black, J.M. (1965) Flora of South Australia, edn 2, vol. 4. (Government Printer: Adelaide.).

Briggs, J. \& J. Leigh (1988) Rare or threatened Australian plants, revised edition. Australian National Parks and Wildlife Service: Canberra, Special Publication 14.

Ewart, A.J. (1931) Flora of Victoria. (Government Printer: Melbourne).

Jessop, J.P. (ed.) (1967) Vascular plants of South Australia, edn 2 (Government Printer: Adelaide). Jessop, J.P. \& H.R. Toelken (eds) (1986) Flora of South Australia, edn 2. (Government Printer: Adelaide).

Maiden, J.H. \& E. Betche (1899) Notes from the Botanic Gardens, Sydney No. 4. Proc. Linn. Soc. New South Wales 24: 143-153.

Maiden, J.H. \& E. Betche (1916) A census of New South Wales plants. (Government Printer: Sydney).

Moore, C. (1884) A census of the plants of New South Wales. (Government Printer: Sydney).

Moore, C. (1893) Handbook of the flora of New South Wales. (Government Printer: Sydney).

Mueller, F. (1860a) Fragmenta phytographiae Australiae 2.

Mueller, F. (1860b) On two alpine Eurybiae of the Australian continent. Papers \& procedings of the Royal Society of Van Diemen's Land 3: 227-230.

Radford, A.E. (1986) Fundamentals of plant systematics. (Harper \& Row: New York).

Wakefield, N.A. (1956) Flora of Victoria: new species and other additions - 10. Victorian Naturalist 73: 96-97.

Willis, J.H. (1973) A handbook to plants in Victoria, vol. 2. (Melbourne University Press: Melbourne).

Manuscript received 29 January 1990

Manuscript accepted 4 September 1990 